\title{
PENGARUH PROFITABILITAS, LIKUIDITAS, KEPEMILIKAN INSTITUSIONAL DAN KEPEMILIKAN MANAJERIAL TERHADAP NILAI PERUSAHAAN
}

\section{Linda Safitri Dewi ${ }^{1}$ Nyoman Abundanti ${ }^{2}$}

${ }^{1,2}$ Fakultas Ekonomi dan Bisnis Universitas Udayana (Unud), Bali, Indonesia email: lindasafitridewi@gmail.com

\begin{abstract}
ABSTRAK
Tujuan utama perusahaan yang sudah go public (perusahaan yang sahamnya tercatat di Bursa Efek Indonesia) yaitu untuk menghasilkan profit guna meningkatkan nilai perusahaan. Penelitian ini bertujuan untuk mengetahui pengaruh profitabilitas, likuiditas, kepemilikan institusional, dan kepemilikan manajerial terhadap nilai perusahaan. Penelitian ini dilakukan pada sektor property dan real estate yang terdaftar pada BEI periode 2014 - 2017, dengan jumlah sampel 11 perusahaan. Pengumpulan data dilakukan dengan metode purposive sampling. Teknis analisis data pada penelitian ini menggunakan analisis regresi linier berganda. Berdasarkan analisis diperoleh hasil bahwa profitabilitas dan kepemilikan manajerial berpengaruh positif dan signifikan terhadap nilai perusahaan, sedangkan likuiditas dan kepemilikan institusional berpengaruh negatif terhadap nilai perusahaan.

Kata kunci: nilai perusahaan; profitabilitas; likuiditas; kepemilikan institusional; kepemilikan manajerial
\end{abstract}

\begin{abstract}
The main purpose of companies that have gone public (companies whose shares are listed on the Indonesia Stock Exchange) is to generate profits to increase the value of the company. This study aims to determine the effect of profitability, liquidity, institutional ownership, and managerial ownership on firm value. This research was conducted on the property and real estate sector which was listed on the Indonesia Stock Exchange for the period 2014-2017, with a sample of 11 companies. Data collection is done by purposive sampling method. Technical data analysis in this study uses multiple linear regression analysis. Based on the analysis obtained results that profitability and managerial ownership have a positive and significant effect on firm value, while liquidity and institutional ownership have a negative effect on firm value.

Keywords: firm value; profitability; liquidity; institutional ownership; managerial ownership
\end{abstract}




\section{PENDAHULUAN}

Perusahaan adalah setiap bentuk badan usaha tempat untuk berkumpulnya tenaga kerja, modal, sumber daya alam yang bertujuan untuk memperoleh keuntungan yang sebesar-besarnya. Perusahaan dikatakan memberikan pengembalian yang menguntungkan bagi pemilik perusahaan serta dapat terus berkembang apabila perusahaan memperoleh profit yang maksimal. Mempertahankan keberlangsungan perusahaan adalah hal penting yang harus dilakukan untuk mempertahankan perusahaan, terutama menyangkut kesejahteraan para pemiliknya. Tujuan utama perusahaan yang sudah go public public (perusahaan yang menawarkan sahamnya pada publik) yaitu untuk menghasilkan profit guna meningkatkan kemakmuran pemegang saham melalui peningkatan nilai perusahaan yang mana dapat menggambarkan keadaan perusahaan. Pandangan perusahaan yang bernilai menurut investor, dilihat dari semakin baik nilai suatu perusahaan (Gultom dkk., 2013) . Nilai perusahaan adalah kinerja perusahaan yang dicerminkan oleh harga saham yang dibentuk oleh permintaan dan penawaran di pasar modal yang merefleksikan penilaian masyarakat terhadap kinerja perusahaan (Harmono, 2009:233).

Nilai perusahaan merupakan hasil dari keputusan keuangan mengenai keputusan investasi, keputusan pendanaan, dan kebijakan dividen. Meningkatkan nilai perusahaan merupakan salah satu cara untuk meningkatkan kemakmuran pemegang saham. Kemakmuran para pemegang saham akan meningkat apabila nilai perusahaan tinggi, sehingga para pemegang saham berkeinginan menginvestasikan modalnya kepada perusahaan tersebut. Dalam teori sinyal dikatakan bahwa pengeluaran investasi oleh investor memberikan sinyal positif tentang pertumbuhan perusahaan dimasa yang akan datang, sehingga dapat meningkatkan nilai perusahaan.

Ada berbagai macam faktor yang mempengaruhi naik turunnya nilai perusahaan diantaranya adalah dengan mengevaluasi laporan keuangan perusahaan dan struktur kepemilikan perusahaan. Faktor - faktor yang mempengaruhi nilai perusahaan, yaitu keputusan pendanaan, kebijakan dividen, keputusan investasi, struktur modal, pertumbuhan perusahaan, ukuran perusahaan. Faktor - faktor yang mempengaruhi nilai perusahaan adalah kebijakan dividen, profitabilitas, pertumbuhan penjualan, dan ukuran perusahaan (Amirya \& Atmini, 2007) dan (Oktaviani, 2008).

Profitabilitas merupakan salah satu faktor yang mempengaruhi nilai perusahaan. Profitabilitas adalah kemampuan perusahaan untuk menghasilkan keuntungan pada tingkat penjualan, aset dan modal tertentu, (Hanafi, 2003:8). Profitabilitas perusahaan memperlihatkan ukuran efektivitas pengelolaan manajemen perusahaan dan menunjukkan kemampuan perusahaan dalam memperoleh laba. Pada saat laba mengalami peningkatan, maka hal tersebut dapat menggambarkan kinerja perusahaan yang baik sehingga menjadi sinyal bagi para pemilik modal untuk berinvestasi di perusahaan yang bersangkutan dan nilai perusahaan akan meningkat (Wiagustini, 2013:86). Penelitian yang dilakukan Chen \& Chen (2011), Safitri et al. (2014), Sucuahi \& Cambarihan (2016), dan Sabrin et al. (2016) menjelaskan bahwa profitabilitas berpengaruh positif signifikan terhadap nilai perusahaan. Berbeda dengan hasil penelitian yang ditemukan oleh Munawaroh 
(2014), Purwohandoko (2017), Zulhilmi et al. (2018) menemukan bahwa profitabilitas berpengaruh negatif signifikan terhadap nilai perusahaan.

Faktor lainnya untuk menilai perusahaan adalah likuiditas, likuiditas merupakan rasio yang menggambarkan kemampuan perusahaan dalam memenuhi kewajiban jangka pendek. Misalnya, membayar gaji, membayar biaya operasional, membayar hutang jangka pendek, dan sebagainya yang membutuhkan pembayaran segera. Perusahaan yang operasionalnya memperoleh laba optimal maka semakin lancar pembiayaan dan pendanaan perusahaan tersebut, begitu juga sebaliknya. Perusahaan yang likuid artinya perusahaan tersebut mampu memenuhi kewajiban - kewajiban jangka pendek, sehingga hal tersebut menjadi sinyal bagi investor untuk berinvestasi yang akan meningkatkan permintaan saham sehingga harga saham perusahaan meningkat. Peningkatan harga saham juga akan meningkatkan nilai perusahaan. Menurut penelitian yang dilakukan oleh Prisilia (2014) dan Tui et al. (2017) mengungkapkan bahwa likuiditas berpengaruh positif signifikan terhadap nilai perusahaan. Berbeda dengan hasil penelitian Nurhayati (2013), Alfi \& Safarzadeh (2016) dan Tahu \& Susilo (2017) mengungkapkan bahwa likuiditas tidak memberikan pengaruh yang signifikan terhadap nilai perusahaan.

Faktor lain yang mempengaruhi nilai perusahaan adalah struktur kepemilikan manajerial dan institusional. Proses memaksimalkan nilai perusahaan akan berdampak pada munculnya konflik kepentingan antara agent (pihak manajemen) dan principal (pemilik perusahaan) yang sering disebut agency problem. Seringkali antara agent dan principal memiliki tujuan yang berbeda. Agent atau pihak manajemen seringkali lebih mementingkan kepentingan sendiri dan menyimpang dari tujuan perusahaan yaitu meningkatkan nilai perusahaan dan menyejahterakan pemilik perusahaan. Perilaku agent inilah yang berdampak kepada penambahan biaya bagi perusahaan yang dapat mempengaruhi nilai perusahaan. Untuk meminimumkan konflik antara manajer dan pemegang saham atau yang disebut sebagai masalah keagenan yaitu dengan suatu mekanisme pengawasan yang dapat mensejajarkan kepentingan-kepentingan tersebut sehingga timbul biaya keagenan (agency cost). Ada beberapa alternatif untuk mengurangi agency cost, diantaranya yaitu dengan adanya kepemilikan saham oleh institusional dan kepemilikan saham oleh manajemen.

Kepemilikan institusional umumnya bertindak sebagai pihak monitor perusahaan. Kepemilikan institusional merupakan proporsi kepemilikan saham pada akhir tahun yang dimiliki oleh lembaga, seperti halnya bank, asuransi atau institusi lain. Kepemilikan institusional mempunyai arti penting dalam memonitor manajemen. Peningkatan pengawasan yang optimal, disebabkan karena adanya kepemilikan oleh institusional. Semakin besar kepemilikan institusional maka semakin efisien pemanfaatan aktiva perusahaan yang diharapkan juga dapat bertindak sebagai pencegahan terhadap pemborosan yang dilakukan oleh pihak manajemen. Menurut hasil penelitian Thanatawee (2014), Jayaningrat, Wahyuni, \& Sujana (2017), dan Yuslirizal (2017), Handayani et al (2018), Ratnawati et al. (2018) menunjukkan kepemilikan institusional berpengaruh positif signifikan terhadap nilai perusahaan. Hasil penelitian tersebut berbeda dengan hasil penelitian Permanasari (2010), Wijaya \& Sedana (2015), dan Rahma (2014) menunjukkan 
bahwa kepemilikan institusional berpengaruh negatif signifikan terhadap nilai perusahaan.

Struktur kepemilikan lain yaitu kepemilikan manajerial dimana adanya kepemilikan saham oleh pihak manajemen akan termotivasi untuk meningkatkan kinerja perusahaan sehingga diharapkan manajer akan bertindak sesuai dengan keinginan para pemegang saham yang nantinya dapat meningkatkan nilai dari perusahaan. Kepemilikan manajerial merupakan kondisi dimana manajer sebagai pemilik dari saham perusahaan, jadi selain sebagai pengelola perusahaan manajer juga merupakan selaku pemilik perusahaan. Pihak manajerial dalam suatu perusahaan adalah pihak yang berperan aktif dalam pengambilan keputusan untuk menjalankan perusahaan. Dewan komisaris dan dewan direksi perusahaan merupakan pihak-pihak yang berperan aktif dalam perusahaan tersebut. Merujuk penelitian yang dilakukan Abbasi, Kalantari, \& Abbasi (2012), Suryanto \& Dai (2016), Hadiwijaya et al. (2016) dan Pratiwi dkk. (2016) menemukan bahwa kepemilikan manajerial berpengaruh positif signifikan terhadap nilai perusahaan. Berbeda halnya dengan hasil penelitian Nurhayati \& Medyawati (2012), Rahmatia \& Andayani (2015), Hatem (2015), Sulistianingsih (2016), dan Alfinur (2016) menemukan bahwa kepemilikan manajerial tidak mempunyai pengaruh signifikan terhadap nilai perusahaan.

Tabel 1.

Sampel Price to Book Value (PBV) pada Sektor Property dan Real Estate yang terdaftar di BEI Periode 2014 - 2017

\begin{tabular}{ccccccc}
\hline \multirow{2}{*}{ No } & \multirow{2}{*}{ Kode Perusahaan } & \multicolumn{3}{c}{ PBV } & $\begin{array}{c}\text { Rata- } \\
\text { rata }\end{array}$ \\
\cline { 3 - 6 } & & $\mathbf{2 0 1 4}$ & $\mathbf{2 0 1 5}$ & $\mathbf{2 0 1 6}$ & $\mathbf{2 0 1 7}$ & 0,62 \\
1 & APLN & 0,87 & 0,75 & 0,45 & 0,4 & 0,38 \\
2 & BAPA & 0,35 & 0,33 & 0,32 & 0,51 & 0,22 \\
3 & BEST & 2,57 & 0,93 & 0,74 & 0,63 & 1,23 \\
4 & DILD & 1,56 & 1,06 & 1,05 & 0,61 & 1,07 \\
5 & GWSA & 0,7 & 1,87 & 0,16 & 0,18 & 0,73 \\
6 & MKPI & 1,87 & 5,66 & 1,87 & 1,87 & 2,82 \\
7 & MTLA & 1,76 & 0,74 & 1,15 & 1,16 & 1,20 \\
8 & PWON & 4,57 & 2,53 & 2,56 & 2,58 & 3,06 \\
9 & RDTX & 1,87 & 1,87 & 1,53 & 0,81 & 1,52 \\
10 & SCBD & 1,49 & 1,39 & 2,09 & 2,09 & 1,77 \\
11 & SMRA & 4 & 3,16 & 2,48 & 1,65 & 2,82 \\
& Rata-rata & 1,96 & 1,84 & 1,31 & 1,14 & 1,56 \\
\hline Sunnnnnnn
\end{tabular}

Sumber: www.idx.co.id (data diolah 2018)

Nilai perusahaan merupakan hal penting bagi semua sektor, tidak terkecuali perusahaan yang bergerak dalam sektor property dan real estate. Pada Tabel 1 dapat dilihat nilai rata - rata PBV mengalami fluktuasi dan cenderung menurun. Ada beberapa faktor yang mempengaruhi PBV mengalami fluktuasi diantaranya yaitu profitabilitas, likuiditas, kepemilikan institusional, dan kepemilikan manajerial. Pada Tabel 1. yang menunjukkan bahwa adanya indikasi fluktuasi nilai rata - rata 
PBV yang cenderung menurun, maka peneliti tertarik untuk melakukan penelitian pada sektor property dan real estate.

Rumusan masalah dalam penelitian ini (1) Bagaimana pengaruh profitabilitas terhadap nilai perusahaan? (2) Bagaimana pengaruh likuiditas terhadap nilai perusahaan? (3) Bagaimana pengaruh kepemilikan institusional terhadap nilai perusahaan? (4) Bagaimana pengaruh kepemilikan manajerial terhadap nilai perusahaan?. Tujuan penelitian ini untuk (1) Untuk menjelaskan pengaruh profitabilitas terhadap nilai perusahaan (2) Untuk menjelaskan pengaruh likuiditas terhadap nilai perusahaan (3) Untuk menjelaskan pengaruh kepemilikan institusional terhadap nilai perusahaan (4) Untuk menjelaskan pengaruh kepemilikan manajerial terhadap nilai perusahaan.

Manfaat penelitian ini yaitu diharapkan dapat menambah pengetahuan, wawasan, serta informasi dan harapannya penelitian ini dapat digunakan sebagai referensi untuk penelitian selanjutnya mengenai nilai perusahaan, dapat dijadikan sebagai referensi bagi perusahaan-perusahaan dalam mengaplikasikan variabelvariabel penelitian ini untuk membantu meningkatkan nilai perusahaan serta diharapkan dapat memberikan informasi bagi perusahaan untuk mengevaluasi, memperbaiki, dan meningkatkan kinerja perusahaan di masa yang akan datang sehingga dapat menarik investor untuk berinvestasi.

Teori sinyal menjelaskan tentang alasan perusahaan memiliki dorongan untuk memberikan informasi laporan keuangan kepada pihak eksternal. Adanya asimetri informasi antara perususahaan dan pihak luar memberikan dorongan kepada perusahaan untuk memberikan informasi karena perusahaan lebih banyak mengetahui prospek perusahaan ke depan. Kurangnya informasi bagi pihak luar mengenai perusahaan mengakibatkan mereka melindungi diri dengan memberikan penilaian yang rendah untuk perusahaan.

Dengan berkurangnya adanya informasi asimetri dalam perusahaan, dapat meningkatkan nilai pada perusahaan. Teori sinyal menjelaskan tentang bagaimana seharusnya sebuah perusahaan memberikan sinyal kepada pengguna laporan keuangan. Sinyal ini dapat berupa informasi mengenai apa yang sudah dilakukan manajemen dalam merealisasikan keinginan pemilik perusahaan.

Agency Theory atau teori keagenan adalah pendesainan kontrak yang tepat untuk menyelaraskan kepentingan prinsipal dan agen dalam hal apabila terjadi konflik kepentingan. Menurut Darmawati \& Khomsiyah (2005) inti dari hubungan keagenan adalah adanya pemisahan antara kepemilikan (principal) dan pengendalian (agent). Salah satu kunci dari teori agensi adalah prinsipal dan agen memiliki tujuan yang berbeda.

Pemisahan antara kepemilikan perusahaan dan pengendalian perusahaan, yang pada dasarnya menyebabkan terjadinya konflik keagenan. Pemilik modal menginginkan bertambahnya kekayaan dan kemakuran bagi pemilik modal, sedangkan manajer juga menginginkan kesejahteraan bagi para manajer. Pemiliki modal lebih tertarik untuk memaksimumkan return dan harga saham dari investasinya, sedangkan manajer ingin memaksimumkan kompensasinya.

Adanya konflik kepentingan antara principal dan agent menyebabkan munculnya agency cost (biaya monitoring). Kontrak yang dibuat antara pricipal dan agent diharapkan mampu meminimumkan konflik antara kedua kepentingan 
tersebut sehingga terjadi hubungan yang sehat bagi para manajer dan dapat memaksimumkan kinerja perusahaan dan juga mengurangi adanya agency cost, sehingga dapat meningkatkan nilai perusahaan dan return yang memadai bagi para pemegang saham.

Nilai perusahaan adalah harga yang bersedia dibayar oleh calon pembeli apabila perusahaan tersebut dijual (Husnan \& Pudjiastuti, 2015:6). Semakin tinggi nilai perusahaan maka semakin tinggi pula kemakmuran para pemegang saham. Nilai saham suatu perusahaan mencerminkan nilai perusahaan. Harga saham yang diperjual - belikan di bursa adalah sebagai tolak ukur nilai perusahaan untuk perusahaan yang menerbitkan saham di pasar modal (Wiagustini, 2013:9). Tujuan utama perusahaan yang merupakan tujuan jangka panjang perusahaan adalah meningkatkan nilai perusahaan yang berarti bahwa manajemen akan selalu berupaya untuk mencapai tujuan tersebut.

Nilai perusahaan dapat menggambarkan keadaan suatu perusahaan. Investor yang berinvestasi di pasar modal memiliki tujuan jangka panjang. Semakin tinggi harga saham, maka semakin tinggi pula keuntungan yang diperoleh para pemegang saham (investor). Meningkatnya harga saham maka nilai perusahaan akan meningkat juga di mata para investor. Tolok ukur yang sering digunakan untuk mengukur nilai perusahaan adalah Price to Book Value (PBV), yang merupakan hasil dari perbandingan antara harga saham dengan nilai buku ekuitas perusahaan. Rasio $P B V$ menunjukkan tingkat kemampuan perusahaan menciptakan nilai relatif terhadap jumlah modal yang diinvestasikan. Nilai perusahaan dapat diukur menggunakan harga sagam perusahaan karena harga pasar saham perusahaan mencerminkan penilaian investor secara keseluruhan atas setiap ekuitas yang dimiliki.

Profitabilitas adalah kemampuan perusahaan dalam menghasilkan keuntungan. Kemampuan memperoleh laba dapat diukur dari seluruh dana yang dimiliki perusahaan atau dari modal sendiri. Dari batasan ini kita bisa mengukur profiabilitas perusahaan apabila kita tahu berapa laba perusahaan yang diperoleh pada periode tertentu dan berapa modal sendiri yang digunakan atau berapa jumlah nilai investasi yang digunakan untuk memperoleh laba tersebut. Investor yang berpotensial akan meganalisis dengan teliti kelancaran sebuah perusahaan dan kemampuannya dalam mendapatkan keuntungan (Fahmi, 2013:116). Semakin baik profitabilitas perusahaan, maka menggambarkan tingginya keuntungan yang diperoleh perusahaan.

Penelitian ini menggunakan Return on Assets (ROA) sebagai proxy dalam menghitung laba perusahaan. $R O A$ merupakan perbandingan laba bersih dengan total aktiva perusahaan. Semakin besar $R O A$ maka menunjukkan kinerja yang semakin baik karena tingkat pengembalian yang diperoleh akan semakin besar, dengan mengetahui rasio ini dapat dinilai apakah perusahaan telah efisien dalam memanfaat aktivanya

Rasio likuiditas merupakan rasio yang diperlukan dalam menganalisis laporan keuangan perusahaan, karena rasio likuiditas merupakan rasio yang menunjukkan kemampuan perusahaan dalam memenuhi kewajiban jangka pendek yang harus segera dipenuhi perusahaan. Likuiditas adalah rasio yang dapat 
menggambarkan kemampuan perusahaan dalam memenuhi kewajiban jangka pendeknya (Kasmir, 2014:129).

Current ratio merupakan rasio yang paling umum digunakan dalam mengukur posisi modal kerja suatu perusahaan, yaitu dengan cara membandingkan jumlah aktiva lancar dengan utang lancar perusahaan, yang termasuk dalam aktiva lancar adalah kas, investasi, piutang wesel, piutang dagang, persediaan, uang muka, sedangkan yang termasuk utang lancar yaitu utang dagang, utang wesel, utang dividen, dan utang bonus.

Kepemilikan institusional adalah kepemilikan saham perusahaan yang dimiliki oleh institusi atau lembaga seperti perusahaan asuransi, bank, perusahaan investasi dan kepemilikan institusi lain (Permanasari, 2010). Pengawasan yang dilakukan oleh pemilik modal akan semakin efektif dan efisien apabila semakin tinggi tingkat konsentrasi kepemilikan saham pihak institusi karena pihak manajemen akan semakin berhati-hati bekerja untuk pemilik modal.

Namun, tindakan monitoring akan berubah dari aktif menjadi pasif dan oportunistik ketika tingkat konsentrasi kepemilikan saham investor institusional semakin besar. Sehingga investor institusional memiliki kekuatan voting yang besar dan nantinya akan berpihak pada pihak manajemen atau bahkan memaksa untuk mengambil keputusan sesuai dengan kepentingannya dan akhirnya mengabaikan tujuan utamanya yaitu meningkatkan nilai perusahaan. Semakin besar kepemilikan institusional akan semakin tinggi nilai perusahaan yang disebabkan reaksi positif pasar akan perbaikan dan pengelolaan perusahaan yang lebih baik. Kepemilikan institusional dapat dihitung dengan menggunakan perbandingan persentase saham yang dimiliki institusi dengan jumlah saham yang beredar.

Kepemilikan manajerial diartikan sebagai persentase saham yang dimiliki oleh pihak manajemen yang meliputi komisaris dan direksi yang secara aktif ikut dalam pengambilan keputusan perusahaan (Midiastuty \& Machfoedz, 2013). Tujuan utama dari perusahaan adalah memaksimalkan keuntungan yang dilakukan oleh pihak manajemen sehingga dapat meningkatkan kesejahteraan pemilik perusahaan. Apabila harga saham di suatu perusahaan meingkat, maka kesejahteraan pemegang saham juga akan meningkat.

Manajemen merupakan pengelola sekaligus pemilik perusahaan akan bertindak demi kepentingan perusahaan apabila saham diberikan kepada manajemen. Untuk itu, kepemilikan manajerial dipandang sebagai alat ukur untuk menyatukan kepentingan anatar manajemen dengan pemilik. Kepemilikan manajerial dapat diukur dengan menggunakan perbandingan persentase kepemilikan saham yang dimiliki direktur dan komisaris dengan jumlah saham yang beredar.

Apabila sebuah perusahaan mampu menggunakan asetnya secara produktif, maka nilai profitabilitas perusahaan tersebut akan meningkat, sehingga dapat menghasilkan keuntungan yang besar pula dalam perusahaan. Hal ini dapat menjadi sinyal positif dan dapat dijadikan sebagai suatu gambaran tentang masa depan perusahaan berdasarkan tingkat profitabilitas yang dihasilkan sesuai dengan konsep dari teori sinyal dan selain itu secara langsung dapat meningkatkan nilai perusahaan yang ditandai dengan semakin meningkatnya harga saham. 
Penelitian yang dilakukan Sabrin et al. (2016), Sucuahi \& Cambarihan (2016), Safitri et al. (2014), dan Chen \& Chen (2011) menyatakan profitabilitas berpengaruh positif signifikan terhadap nilai perusahaan.

$\mathrm{H}_{1}$ : Profitabilitas berpengaruh positif dan signifikan terhadap nilai perusahaan.

Semakin baik kemampuan perusahaan dalam memenuhi kewajiban jangka pendeknya, maka semakin tinggi rasio yang dihasilkan. Selain itu ketersediaan dana perusahaan dalam melakukan operasi perusahaan dan pembayaran dividen dapat digambarkan dari tinggi rendahnya rasio likuiditas. Para investor akan memiliki persepsi bahwa perusahaan tersebut memiliki kinerja yang baik jika perusahaan memiliki tingkat likuiditas yang tinggi yang tentunya akan dianggap menjadi prospek yang bagus di masa depan sehingga bisa meningkatkan harga saham perusahaan dan nilai perusahaan akan meningkat.

Menurut penelitian yang dilakukan oleh Tui et al. (2017) menyatakan likuiditas berpengaruh positif signifikan terhadap nilai perusahaan. Penelitian tersebut juga didukung Prisilia (2014) yang mengungkapkan likuiditas berpengaruh positif signifikan terhadap nilai perusahaan.

$\mathrm{H}_{2}$ : Likuiditas berpengaruh positif dan signifikan terhadap nilai perusahaan.

Kepemilikan saham oleh institusi memiliki penting dalam hal pengawasan yang lebih optimal kepada manajemen sehingga mampu menekan perilaku oportunistik yang tidak sesuai dengan tujuan perusahaan yang mungkin dilakukan oleh pihak manajemen sehungga dapat memantau dalam hal pengambilan keputusan perusahaan. Pengawasan tersebut mendorong peningkatan kinerja manajemen dan berdampak positif pada nilai perusahaan. Semakin besar tingkat kepemilikan institusional maka semakin optimal tingkat pengendalian yang dilakukan oleh pihak eksternal terhadap perusahaan sehingga agency cost yang terjadi di dalam perusahaan semakin berkurang dan nilai perusahaan juga semakin meningkat.

Institusional berpengaruh positif signifikan terhadap nilai perusahaan (Jayaningrat et al., 2017) . Kepemilikan institusional berpengaruh positif signifikan terhadap nilai perusahaan (Yuslirizal, 2017) dan (Nuraina, 2017).

$\mathrm{H}_{3}$ : Kepemilikan institusional berpengaruh positif dan signifikan terhadap nilai perusahaan.

Apabila proporsi kepemilikan manajerial pada suatu perusahaan itu besar, maka manajemen akan cenderung lebih giat dalam meningkatkan nilai perusahaan untuk kepentingan pemegang saham dimana pemegang sahamnya adalah dirinya sendiri. Dengan adanya motivasi tersebut, maka manajer akan berusaha semaksimal mungkin untuk memaksimalkan nilai perusahaan.

Kepemilikan manajerial berpengaruh positif sigifikan terhadap nilai perusahaan (Pratiwi, 2016). Penelitian tersebut juga didukung oleh penelitian Hadiwijaya et al. (2016), Suryanto \& Dai (2016), Abbasi, Kalantari, \& Abbasi (2012) yang juga menyatakan bahwa kepemilikan manajerial berpengaruh positif signifikan terhadap nilai perusahaan.

$\mathrm{H}_{4}$ : Kepemilikan manajerial berpengaruh positif dan signifikan terhadap nilai perusahaan. 


\section{METODE PENELITIAN}

Penelitian ini merupakan penelitian kuantitatif yang berbentuk asosiatif, yaitu untuk mengetahui pengaruh antara profitabilitas, likuiditas, kepemilikan institusional, dan kepemilikan manajerial terhadap nilai perusahaan pada perusahaan - perusahaan property dan real estate di BEI. Penelitian ini dilakukan terhadap perusahaan - perusahaan sektor property dan real estate yang terdaftar pada Bursa Efek Indonesia (BEI) dengan cara mengakses situs resmi BEI di www.idx.co.id. Obyek penelitian ini adalah nilai perusahaan (PBV), Nilai perusahaan tersebut diukur menggunakan Profitabilitas (ROA), Likuiditas (CR), Kepemilikan Institusional (KI), dan Kepemilikan Manajerial (KM).

Berdasarkan penelitian yang dilakukan oleh Nurhayati (2013) PBV yang diukur dalam satuan persentase dengan rumus sebagai berikut.

$$
\mathrm{PBV}=\frac{\text { Harga per lembar saham }}{\text { Nilai buku per lembar saham }} \times 100 \%
$$

Nurhayati (2013) menggunakan ROA sebagai proksi untuk menghitung profitabilitas perusahaan yang diukur dalam satuan persentase dengan rumus sebagai berikut.

$$
\mathrm{ROA}=\frac{\text { Laba Bersih }}{\text { Total Aktiva Perusahaan }} \times 100 \%
$$

Nurhayati (2013) menggunakan Current Ratio (CR) sebagai proksi untuk menghitung likuiditas perusahaan yang diukur dalam satuan persentase dengan rumus sebagai berikut.

$$
\text { Current Ratio }=\frac{\text { Aktiva Lancar }}{\text { Utang Lancar }} \times 100 \%
$$

Menghitung persentase kepemilikan saham yang dimiliki oleh institusi atau lembaga menggunakan rumus sebagai berikut.

$$
\mathrm{KI}=\frac{\text { Jumlah Saham Institusional }}{\text { Jumlah Saham Beredar }} \times 100 \%
$$

Menghitung persentase kepemilikan saham yang dimiliki manajer adalah menggunakan rumus sebagai berikut.

$$
\mathrm{KM}=\frac{\text { Kepemilikan saham oleh manajer,direktur,komisaris }}{\text { Jumlah saham beredar }} \times 100 \%
$$

Populasi dalam penelitian ini adalah seluruh perusahaan property dan real estate yang terdaftar di BEI yang berjumlah 55 perusahaan. Metode penentuan sampel yang digunakan adalah teknik purposive sampling. Teknik purposive sampling merupakan teknik penentuan sampel dengan menggunakan pertimbangan atau kriteria tertentu. Perusahaan yang memenuhi syarat dari kriteria penentuan sampel sebanyak 11 perusahaan yang terdaftar di BEI pada periode $2014-2017$.

Jenis data yang digunakan dalam penelitian ini ada dua, yaitu data kuantitatif berupa laporan keuangan perusahaan property dan real estate yang terdaftar di EI) 
periode 2014 - 2017 dan data kualitatifnya berupa gambaran umum perusahaan property dan real estate yang terdaftar di BEI.

Teknik analisis yang digunakan pada penelitian ini berupa uji asumsi klasik yaang terdiri dari uji normalitas, uji autokorelasi, uji heteroskedastisitas, dan uji multikolinieritas, serta uji analisis regresi linier berganda untuk melihat hubungan antara variabel dependen dengan variabel independen apakah memiliki hubungan yang positif atau negatif. Setelah melakukan teknik analisis regresi linier berganda maka dilakukan uji hipotesis yaitu uji t, uji kelayakan model, dan uji koefisien determinasi majemuk.

\section{HASIL DAN PEMBAHASAN}

Berikut ini merupakan hasil dari penelitian setelah diolah datanya beserta penjelan dari hasil penelitian.

Tabel 2.

Hasil Analisis Statistik Deskriptif

\begin{tabular}{lccccc}
\hline & N & Minimum & Maximum & Mean & $\begin{array}{l}\text { Std. } \\
\text { Deviation }\end{array}$ \\
\hline Nilai Perusahaan & 44 & 0,16 & 5,66 & 1,5360 & 1,17417 \\
Profitabilitas & 44 & 0,01 & 0,15 & 0,0569 & 0,03345 \\
Likuiditas & 44 & 0,26 & 8,80 & 2,2757 & 1,69761 \\
Kepemilikan & 44 & 0,37 & 0,91 & 0,6614 & 0,14950 \\
$\begin{array}{l}\text { Institusional } \\
\text { Kepemilikan }\end{array}$ & 44 & 0,00 & 6,02 & 0,7953 & 1,74917 \\
$\begin{array}{l}\text { Manajerial } \\
\text { Valid N (listwise) }\end{array}$ & 44 & & & & \\
\hline Sumber Data diolah (2018) & & & & & \\
\end{tabular}

Berdasarkan Tabel 2. memperlihatkan hasil uji statistik deskriptif masing masing variabel sebagai berikut.

Variabel terikat dari penelitian ini, yaitu nilai perusahaan yang diproksikan dengan PBV memiliki nilai minimum sebesar 0,16 yang dimiliki oleh perusahaan Greenwood Sejahtera Tbk. (GWSA) pada tahun 2016, sedangkan nilai maksimum yang diperoleh sebesar 5,66 dimiliki oleh perusahaan Metropolitan Kentjana Tbk. (MKPI) pada tahun 2015. Rata - rata yang diperoleh nilai perusahaan pada perusahaan property dan real estate yang terdaftar di BEI periode 2014 - 2017 sebesar 1,56 dengan standar deviasi 1,17. Variabel Profitabilitas (ROA) memiliki nilai minimum sebesar 0,01 yang dimiliki oleh perusahaan Bekasi Asri Pemula (BAPA) pada tahun 2015, sedangkan untuk nilai maksimum yang diperoleh adalah 0,15 yang dimiliki oleh perusahaan Metropolitan Kentjana Tbk. (MKPI) pada tahun 2015. Nilai rata - rata yang dimiliki oleh variabel profitabilitas untuk perusahaan property dan real estate di BEI periode 2014 - 2017 sebesar 0,05. Variabel likuiditas (CR) memiliki nilai minimum sebesar 0,26 yang dimiliki oleh perusahaan Agung Podomoro Land Tbk. (APLN) pada tahun 2014, sedangkan untuk nilai maksimum yang diperoleh adalah 8,80 dimiliki oleh perusahaan Greenwood Sejahtera Tbk. (GWSA) pada tahun 2016. Nilai rata - rata yang diperoleh likuiditas 
pada perusahaan property dan real estate yang terdaftar di BEI periode $2014-2017$ sebesar 2,27 dengan standar deviasi 1,69. Variabel Kepemilikan Institusional (KI) mempunyai nilai minimum sebesar 0,37 yang dimiliki oleh perusahaan Summarecon Agung Tbk. (SMRA) tahun 2014, sedangkan untuk nilai maksimum yang diperoleh adalah 0,91 dimiliki oleh perusahaan Danayasa Arthatama Tbk. (SCBD) pada tahun 2017. Nilai rata - rata yang diperoleh kepemilikan institusional pada perusahaan property dan real estate yang terdaftar di BEI periode 2014-2017 sebesar 0,66 dengan standar deviasi 1,49. Variabel Kepemilikan Manajerial (KM) nilai minimumnya sebesar 0,0003 dimiliki oleh perusahaan Pakuwon Jati Tbk. (PWON) pada tahun 2014, untuk nilai maksimumnya diperoleh sebesar 6,02 dimiliki oleh perusahaan Danayasa Arthatama Tbk. (SCBD) pada tahun 2014. Nilai rata - rata yang diperoleh kepemilikan manajerial pada perusahaan property dan real estate yang terdaftar di BEI periode 2014 - 2017 sebesar 0,79 dengan standar deviasi 1,74 .

Tabel 3.

Hasil Uji Normalitas

\begin{tabular}{llr}
\hline & & Unstandardized Residual \\
\hline $\mathrm{N}$ & & 44 \\
Normal Parameters & $\mathrm{a}, \mathrm{b}$ & 0,0000000 \\
& Mean & 0,63821673 \\
Most Extreme Differences & Std. Deviation & 0,119 \\
& Absolute & 0,119 \\
& Positive & $-0,062$ \\
& Negative & 0,792 \\
Kolmogorov-Smirnov $\mathrm{Z}$ & & 0,556 \\
Asymp. Sig. (2-tailed) & &
\end{tabular}

Berdasarkan Tabel 3. hasil uji Kolmogorov-Smirnov nilai signifikansinya sebesar 0,556 maka dapat diambil kesimpulan bahwa data residual terdistribusi normal karena signifikansi nilai Asymp. Sig. (2-tailed) lebih besar dari 0,05.

Tabel 4.

Hasil Uji Autokorelasi

\begin{tabular}{ccccr}
\hline Model & R & R Square & $\begin{array}{c}\text { Adjusted R } \\
\text { Square }\end{array}$ & $\begin{array}{c}\text { Durbin- } \\
\text { Watson }\end{array}$ \\
\hline 1 & $0,839^{\mathrm{a}}$ & 0,705 & 0,674 & 1,969 \\
\hline
\end{tabular}

Sumber: Data diolah (2018)

Berdasarkan Tabel 4. memperlihatkan hasil durbin watson yang diperoleh sebesar 1,969. Model regresi tidak terdapat autokorelasi dengan kriteria $\mathrm{d}_{\mathrm{u}}<\mathrm{d}<4-\mathrm{d}_{\mathrm{u}}$. Pada penelitian ini diperoleh nilai $\mathrm{d}_{\mathrm{u}}=1,72$, maka $1,72<1,969<2,28$ dapat disimpulkan tidak terdapat autokorelasi pada penelitian ini. 
Berdasarkan Tabel 5. menunjukkan hasil tolerance dan VIF masing - masing variabel yang memiliki nilai tolerance lebih dari 10 persen dan nilai VIF dibawah 10. Berdasarkan hasil tersebut maka dapat disimpulkan bahwa model regresi dalam penelitian ini tidak mengandung gejala multikolinearitas antar variabel bebas.

Tabel 5.

Hasil Uji Multikolinearitas

\begin{tabular}{lcc}
\hline \multicolumn{1}{c}{ Variabel } & \multicolumn{2}{c}{ Collinearity Statistics } \\
\cline { 2 - 3 } & Tolerance & VIF \\
\hline Profitabilitas & 0,854 & 1,171 \\
Likuiditas & 0,749 & 1,334 \\
Kepemilikan Institusional & 0,759 & 1,318 \\
Kepemilikan Manajerial & 0,681 & 1,468 \\
\hline
\end{tabular}

Sumber : Data diolah (2018)

Tabel 6.

Hasil Uji Heteroskedastisitas

\begin{tabular}{llrrrrr}
\hline \multirow{2}{*}{ Model } & & \multicolumn{2}{c}{$\begin{array}{c}\text { Unstandardized } \\
\text { Coefficients }\end{array}$} & $\begin{array}{c}\text { Standardized } \\
\text { Coefficients }\end{array}$ & & \\
\cline { 3 - 5 } & & B & \multicolumn{1}{c}{$\begin{array}{c}\text { Std. } \\
\text { Eror }\end{array}$} & Beta & & t \\
\hline 1 & & & & & Sig. \\
& (Constant) & 0,743 & 2,80 & & 2,651 & 0,012 \\
& ROA & 2,001 & 1,869 & 0,176 & 1,071 & 0,291 \\
& CR & 0,045 & 0,039 & 0,200 & 1,142 & 0,261 \\
& KI & $-0,690$ & 0,444 & $-0,271$ & $-1,554$ & 0,128 \\
& KM & 0,004 & 0,040 & 0,020 & 0,106 & 0,916 \\
\hline
\end{tabular}

Sumber: Data diolah (2018)

Menurut hasil pengujian, tingkat signifikansi variabel bebas berada di atas 0,05 , sehingga dapat dikatakan bahwa dalam model regresi ini tidak terdapat heteroskedastisitas.

Tabel 7.

Analisis Regresi Linier Berganda

\begin{tabular}{|c|c|c|c|c|c|}
\hline \multirow{2}{*}{\multicolumn{2}{|c|}{ Model }} & \multicolumn{2}{|c|}{$\begin{array}{c}\text { Unstandardized } \\
\text { Coefficients }\end{array}$} & \multirow{2}{*}{$\begin{array}{c}\begin{array}{c}\text { Collinearity } \\
\text { Statistics }\end{array} \\
\text { Tolerance }\end{array}$} & \multirow[b]{2}{*}{ VIF } \\
\hline & & B & $\begin{array}{l}\text { Std. } \\
\text { Eror }\end{array}$ & & \\
\hline \multirow[t]{5}{*}{1} & (Constant) & 1,840 & 0,496 & & \\
\hline & ROA & 27,340 & 3,306 & 0,854 & 1,171 \\
\hline & CR & $-0,089$ & 0,070 & 0,749 & 1,334 \\
\hline & $\mathrm{KI}$ & $-2,709$ & 0,785 & 0,759 & 1,316 \\
\hline & $\mathrm{KM}$ & 0,204 & 0,071 & 0,681 & 1,468 \\
\hline
\end{tabular}

Sumber: Data diolah (2018)

Berdasarkan Tabel 7, maka dapat dibentuk persamaan regresi linier berganda pada penelitian ini yaitu sebagai berikut.

$Y=1,840+27,34 X_{1}-0,089 X_{2}-2,709 X_{3}+0,204 X_{4}$ 
Tabel 8.

Uji Hipotesis (Uji t)

\begin{tabular}{|c|c|c|c|c|c|c|}
\hline \multirow[b]{2}{*}{ Model } & & \multicolumn{2}{|c|}{$\begin{array}{l}\text { Unstandardized } \\
\text { Coefficients }\end{array}$} & \multirow{2}{*}{$\begin{array}{c}\begin{array}{c}\text { Standardized } \\
\text { Coefficients }\end{array} \\
\text { Beta }\end{array}$} & \multirow[b]{2}{*}{$\mathbf{t}$} & \multirow[b]{2}{*}{ Sig. } \\
\hline & & B & $\begin{array}{l}\text { Std. } \\
\text { Eror }\end{array}$ & & & \\
\hline \multirow[t]{5}{*}{1} & (Constant) & 1,840 & 0,496 & & 3,710 & 0,001 \\
\hline & $\mathrm{ROA}$ & 27,340 & 3,306 & 0,779 & 8,270 & 0,000 \\
\hline & CR & $-0,089$ & 0,070 & $-0,128$ & $-1,276$ & 0,210 \\
\hline & KI & $-2,709$ & 0,785 & $-3,452$ & $-3,452$ & 0,001 \\
\hline & KM & 0,204 & 0,071 & 0,304 & 2,886 & 0,006 \\
\hline
\end{tabular}

Sumber : Data diolah (2018)

Pengaruh variabel profitabilitas terhadap nilai perusahaan ditemukan koefisien regresi sebesar 27,340 dan Sig.t $=0,000<0,05$, maka hipotesis diterima, ini menunjukkan bahwa profitabilitas berpengaruh positif dan signifikan secara parsial terhadap nilai perusahaan.

Pengaruh variabel likuiditas terhadap nilai perusahaan ditemukan koefisien regresi sebesar $-0,089$ dan Sig.t $=0,210>0,05$, yang artinya hipotesis ditolak, ini menunjukkan likuiditas berpengaruh negatif secara parsial terhadap nilai perusahaan. Pengaruh variabel kepemilikan institusional terhadap nilai perusahaan ditemukan koefisien regresi -2,709 dan Sig.t $=0,001<0,05$, maka hipotesis ditolak, ini berarti kepemilikan institusional berpengaruh negatif dan signifikan secara parsial terhadap nilai perusahaan.

Pengaruh variabel kepemilikan manajerial terhadap nilai perusahaan ditemukan koefisien regresi 0,204 dan Sig.t $=0,006<0,05$, maka hipotesis diterima, ini menunjukkan bahwa kepemilikan manajerial berpengaruh positif dan signifikan secara parsial terhadap nilai perusahaan.

Tabel 9.

Hasil Uji Kelayakan Model

\begin{tabular}{llcrrrr}
\hline Model & & $\begin{array}{c}\text { Sum of } \\
\text { Squares }\end{array}$ & df & \multicolumn{1}{c}{$\begin{array}{c}\text { Mean } \\
\text { Square }\end{array}$} & F & Sig. \\
\hline 1 & Regression & 41,768 & 4 & 10,442 & 23,251 & $0,000^{\text {a }}$ \\
& Residual & 17,515 & 39 & 0,449 & & \\
& Total & 59,283 & 43 & & & \\
\hline
\end{tabular}

Sumber: Data diolah (2018)

Berdasarkan hasil yang diperoleh nilai signifikansi 0,000 , sehingga model ini layak digunakan sebagai penelitian. Hal ini menunjukkan bahwa ada pengaruh secara bersama-sama antara variabel bebas yaitu tingkat Profitabilitas (ROA), Likuiditas (CR), Kepemilikan Institusional (KI), dan Kepemilikan Manajerial (KM) terhadap Nilai Perusahaan (PBV).

Tabel 10.

Hasil Uji $\mathbf{R}^{2}$ (Koefisien Determinasi) 


\begin{tabular}{lrrrr}
\hline Model & R & R Square & $\begin{array}{c}\text { Adjusted R } \\
\text { Square }\end{array}$ & $\begin{array}{l}\text { Std. Error of } \\
\text { the Estimate }\end{array}$ \\
\hline 1 & $0,839^{\mathrm{a}}$ & 0,705 & 0,674 & 0,67015 \\
\hline Sumber: Data diolah (2018) & & & &
\end{tabular}

Berdasarkan Tabel 10. menunjukkan hasil adjusted $\mathrm{R}^{2}$ sebesar 0,674, yang berarti bahwa sebesar 67,4 persen perubahan nilai perusahaan pada perusahaan property dan real estate yang terdaftar di BEI selama periode 2014 - 2017 dipengaruhi oleh variabel profitabilitas, likuiditas, kepemilikan institusional, dan kepemilikan manajerial, sedangkan sisanya sebesar 32,6 persen dipengaruhi oleh variabel lain di luar model regresi.

Hasil uji menunjukkan bahwa variabel profitabilitas memiliki tingkat signifikansi sebesar $0,000<0,05$ dengan koefisien regresi sebesar 27,340 berarti bahwa hipotesis diterima, yang artinya profitabilitas berpengaruh positif dan signifikan terhadap nilai perusahaan. Hal ini menunjukkan bahwa profitabilitas mampu mempengaruhi nilai perusahaan pada perusahaan property dan real estate di BEI periode 2014 - 2017. Hal ini berarti bahwa semakin tinggi tingkat profitabilitas yang dimiliki perusahaan, maka semakin tinggi pula nilai sebuah perusahaan.

Profitabilitas yang tinggi dapat menarik para investor untuk menanamkan modalnya pada perusahaan. Profit yang tinggi akan memberikan indikasi prospek perusahaan yang baik sehingga dapat memicu investor untuk ikut meningkatkan permintaan saham, sehingga harga saham meningkat yang menyebabkan nilai perusahaan juga meningkat. Semakin besar ROA yang diperoleh suatu perusahaan, maka tingkat efisiensi penggunaan aktiva semakin besar, begitu sebaliknya. Semakin kecil ROA yang dimiliki oleh suatu perusahaan, maka semakin kecil pula tingkat efisiensi penggunaan aktiva (Istikhanah, 2015). Hasil penelitian ini sejalan dengan hasil penelitian Chen \& Chen (2011), Safitri et al. (2014), Sucuahi \& Cambarihan (2016), dan Sabrin et al. (2016) yang menemukan bahwa profitabilitas berpengaruh positif dan signifikan terhadap nilai perusahaan.

Hasil pengujian menunjukkan bahwa variabel likuiditas tingkat signifikansinya sebesar $0,210>0,05$ dengan koefisien regresi $-0,089$ yang artinya hipotesis ditolak, ini menunjukkan bahwa likuiditas berpengaruh negatif terhadap nilai perusahaan property dan real estate di BEI periode 2014-2017. Current ratio yang terlalu tinggi dianggap kurang baik karena menunjukkan banyaknya dana yang menganggur sehingga dapat mempengaruhi kemampuan memperoleh laba, begitu pun sebaliknya current ratio yang rendah dianggap menunjukkan adanya masalah dalam likuidasi (Sawir, 2009:10).

Hasil uji menunjukkan terdapat pengaruh yang negatif terhadap nilai perusahaan. Pengaruh negatif ini disebabkan karena apabila aktiva lancar yang dimiliki perusahaan ini semakin tinggi berarti ada dana yang menganggur di perusahaan, yang mengakibatkan perusahaan tidak dapat secara optimal memanfaatkan aktiva lancarnya sehingga perusahaan tidak mampu memakmurkan para pemegang saham. Bertentangan dengan halnya ketika perusahaan ingin meningkatkan nilai perusahaan, maka perusahaan harus mampu memakmurkan pemegang sahamnya. Hasil penelitian ini sejalan dengan dengan Nugroho (2012), 
Nurhayati (2013) dan Wulandari (2014), yang menyatakan bahwa likuiditas berpengaruh negatif namun tidak signifikan terhadap nilai perusahaan.

Hasil dari pengujian menunjukkan variabel kepemilikan institusional mempunyai tingkat signifikansi sebesar 0,001 dengan koefisien regresi sebesar $-2,709$ yang artinya hipotesis ditolak yaitu kepemilikan institusional berpengaruh negatif dan signifikan terhadap nilai perusahaan property dan real estate di Bursa Efek Indonesia (BEI) periode 2014-2017. Kepemilikan institusional ini merupakan kepemilikan mayoritas karena memiliki rata-rata sebesar $66,14 \%$. Investor institusional mayoritas memiliki kecenderungan untuk berpihak kepada manajemen dan mengabaikan kepentingan pemegang saham minoritas.

Anggapan bahwa manajemen sering mengambil tindakan atau kebijakan yang tidak optimal dan cenderung mengarah pada kepentingan pribadi mengakibatkan strategi aliansi antara investor institusional dengan pihak manajemen akan menjadi sinyal negatif bagi pihak luar. Tindakan ini akan merugikan operasional perusahaan. Dampaknya, investor tidak akan tertarik untuk menanamkan modalnya yang mengakibatkan volume perdagangan saham perusahaan akan menurun, sehingga harga saham perusahaan pun menurun dan nilai perusahaan juga akan menurun. Hasil penelitian ini sejalan dengan Permanasari (2010), Rahma (2014), dan Alfinur (2016), yang menemukan kepemilikan institusional berpengaruh negatif dan signifikan terhadap nilai perusahaan.

Hasil pengujian menunjukkan variabel kepemilikan manajerial mempunyai tingkat signifikansi $0,006<0,05$, dengan koefisien regresi sebesar 0,204 yang artinya hipotesis diterima yaitu kepemilikan manajerial berpengaruh positif dan signifikan terhadap nilai perusahaan property dan real estate di BEI periode 2014 - 2017. Kepemilikan manajerial dianggap sebagai salah satu faktor yang mempengaruhi nilai perusahaan, karena dengan adanya kepemilikan manajerial akan mensejajarkan kepentingan antara manajemen dan pemegang saham (Juhandi et al., 2013).

Adanya proporsi kepemilikan manajerial yang tinggi, menyebabkan manajemen cenderung akan bekerja lebih giat untuk kepentingan pemegang saham yang notabene adalah dirinya sendiri sehingga dapat meningkatkan nilai perusahaan. Selain itu, kepemilikan manajerial dapat membantu penyatuan kepentingan antara pemegang saham dengan manajemen, karena manajemen dan pemegang saham dari pihak luar memiliki tujuan yang sama, sehingga hal tersebut dapat mengurangi konflik keagenan yang dapat meningkatkan nilai perusahaan. Hasil penelitian ini sejalan dengan Abbasi, Kalantari, \& Abbasi (2012), Suryanto \& Dai (2016), Hadiwijaya et al. (2016), dan Pratiwi dkk. (2016) yang menemukan kepemilikan manajerial berpengaruh positif dan signifikan terhadap nilai perusahaan.

\section{SIMPULAN}

Simpulan yang dapat diambil berdasarkan hasil analisis adalah sebagai berikut: 1) Profitabilitas berpengaruh positif dan signifikan terhadap nilai perusahaan. Hal ini menunjukkan semakin tinggi nilai profitabilitas perusahaan maka nilai perusahaan akan semakin menigkat. 2) Likuiditas berpengaruh negatif 
namun tidak signifikan terhadap nilai perusahaan. Hal ini menunjukkan semakin tinggi likuiditas perusahaan maka nilai perusahaan akan semakin menurun. 3) Kepemilikan Institusional berpengaruh negatif dan signifikan terhadap nilai perusahaan. Hal ini menunjukkan semakin tinggi kepemilikan institusional perusahaan maka nilai perusahaan akan semakin menurun. 4) Kepemilikan Manajerial berpengaruh positif dan signifikan terhadap nilai perusahaan. Hal ini menunjukkan semakin tinggi kepemilikan manajerial perusahaan maka nilai perusahaan akan semakin meningkat.

Saran yang dapat diberikan pada penelitian ini, berdasarkan pada hasil analisis, pembahasan dan simpulan adalah sebagai berikut: 1) Bagi pihak perusahaan, diharapkan dapat lebih memperhatikan faktor-faktor yang berdampak bagi nilai perusahaan yaitu faktor profitabilitas dan kepemilikan manajerial. Hal ini dikarenakan profitabilitas dan kepemilikan manajerial berpengaruh positif signifikan terhadap nilai perusahaan. 2) Bagi peneliti selanjutnya dapat melakukan penelitian dengan meneliti variabel-variabel lain yang memengaruhi nilai pada perusahaan property dan real estate yang terdaftar di Bursa Efek Indonesia, serta dapat menambah periode waktu penelitian.

\section{REFERENSI}

Abbasi, M., Kalantari, E., \& Abbasi, H. (2012). Impact of Corporate Governance Mechanism on Firm Value: Evidence From The Food Industry in Iran. Journal of Basic and Applied Scientific Research, 5(2), 4712-4721. Retrieved from www.nfcgindia.org

Alfi, S., \& Safarzadeh, M. H. (2016). Effect of capital structure andliquidity on firm value. International Journal of Applied Business and Economic Research, 14(14), 817-827. Retrieved from www.serialsjounal.com/serialjournalmanager/1485344935

Alfinur. (2016). Pengaruh Mekanisme Good Corporate Governanace (GCG) terhadap Nilai Perusahaan pada Perusahaan yang Listing di BEI. Jurnal Ekonomi Modernisasi, 12(1), 44-50. https://doi.org/10.21067/jem.v12i1.1178

Amirya, M., \& Atmini, S. (2007). Faktor-Faktor yang Mempengaruhi Nilai Perusahaan yang Dimediasi Oleh Leverage Perusahaan Sebagai Variabel Intervening: Sebuah Perpektif Pecking Order Theory. Jurnal Akuntansi Dan Keungan, 2(2), 1-25.

Chen, L.-J., \& Chen, S.-Y. (2011). The influence of profitability on firm value with capital structure as the mediator and firm size and industry as moderators. Investment Management and Financial Innovations Journal, 8(3), 121-129. Retrieved from https://businessperspectives.org/images/pdf/applications/publishing/template s/article/assets/4210/imfi_en_2011_03_Chen

Darmawati, D., \& Khomsiyah, R. G. R. (2005). Hubungan Corporate Governance 
dan Kinerja Perusahaan. Jurnal Riset Akuntansi Indonesia, 8(6), 65-81. Retrieved from https://ijar-iaikapd.or.id/index.php/ijar/article/view/131

Fahmi, I. (2013). Pengantar Manajemen Keuangan. Bandung: Alfabeta.

Gultom, Robinhot, Agustina, dan Wijaya, S. W. (2013). Analisis Faktor-Faktor Yang Mempengaruhi Nilai Perusahaan Pada Perusahaan Farmasi Di Bursa Efek Indonesia. Jurnal Wira Ekonomi Mikrosil, 3(1), 51-60. https://doi.org/MS08584

Hadiwijaya, T., Lahindah, L., \& Pratiwi, I. R. (2016). Effect Of Capital Structure And Corporate Governance On Firm Value (Study Of Listed Banking Companies In Indonesia Stock Exchange). Journal Of Accounting And Business Studies, 1(1), 21-37. Retrieved from https://www.researchgate.net/publication/309000352

Handayani, I. A. R. P., Ariyanto, D., Rasmini, N. K., \& Widanaputra, A. A. G. P. (2018). The Effect of Profitability , Institutional Ownership on the Value of the Company with Dividend Policy as a Meditation. International Journal of Sciences Basic and Applied Research (IJSBAR), 41(1), 234-242. Retrieved from http://gssrr.org/index.php?journal=JournalOfBasicAndApplied

Harmono. (2009). Manajemen Keuangan. Jakarta: PT Bumi Aksara.

Hatem, B. S. (2015). Interdependence between Managerial Ownership, Leverage and Firm Value: Theory and Empirical Validation. International Journal of Economics and Finance, 7(12), 106-118. https://doi.org/10.5539/ijef.v7n12p106

Husnan, S., \& Pudjiastuti, E. (2015). Dasar-dasar Manajemen Keuangan Edisi Ketujuh. Yogyakarta: UPP STIM YKPN.

Istikhanah. (2015). Pengaruh Return On Assets (ROA) dan Return on Equity (ROE) terhadap Nilai perusahaan (Skripsi). UNNES.

Jayaningrat, I. G. A. A., Wahyuni, M. A., \& Sujana, E. (2017). Pengaruh Leverage, Profitabilitas, Likuiditas, Kebijakan Deviden, Kepemilikan Manajerial, dan Kepemilikan Institusional Terhadap Nilai Perusahaan Pada Perusahaan Properti dan Real Estate di Bursa Efek Indonesia Tahun 2013-2015. E-Journal S1 Ak Universitas Pendidikan Ganesha, 1(1), 1-12.

Juhandi, N., Sudarma, M., Aisjah, S., \& Rofiaty. (2013). The Effects of Internal factors and Stock Ownership Structure on Dividend Policy on Company's Value A Study on Manufacturing Companies Listed on the Indonesia Stock Exchange (IDX). International Journal of Business and Management Invention, 2(11), 6-18. https://doi.org/10.1098/rsta.2009.0153 
Kasmir. (2014). Analisis Laporan Keuangan, Edisi Satu. Jakarta: PT Raja Grafindo Persada.

Midiastuty, P. P., \& Machfoedz, M. (2013). Analisis Hubungan Mekanisme Corporate Governance dan Indikasi Manajemen Laba. Simposium Nasional Akuntansi VI, 6(9), 176-198. Retrieved from http://pdeb.fe.ui.ac.id/?p=11069

Munawaroh, A. (2014). Pengaruh Profitabilitas Terhadap Nilai Perusahaan dengan Corporate Social Responsibility Sebagai Variabel Moderating. Jurnal Ilmu Dan Riset Akuntansi, 3(4), 1-17.

Nugroho, W. A. (2012). Pengaruh Profitabilitas, Likuiditas, dan Leverage terhadap Nilai Perusahaan (Tesis). Universitas Muhammadiyah Surakarta.

Nur Safitri, O., Ragil Handayani, S., \& Firdausi Nuzula, N. (2014). The Influence of Capital Structure and Proftability on Firm Value ( A Study in Retail Companies Listed in Indonesia Stock Exchange 2010-2013 period ). Jurnal Administrasi Bisnis, 13(2), 1-19.

Nuraina, E. (2017). Pengaruh Kepemilikan Institusional Dan Ukuran Perusahaan Terhadap Kebijakan Hutang Dan Nilai Perusahaan (Studi Pada Perusahaan Manufaktur Yang Terdaftar Di BEI). AKRUAL: Jurnal Akuntansi, 4(1), 51. https://doi.org/10.26740/jaj.v4n1.p51-70

Nurhayati. (2013). Profitabilitas, Likuiditas, dan Ukuran Perusahaan Pengaruhnya terhadap Kebijakan Dividen dan Nilai Perusahaan Sektor Non Jasa. Jurnal Keuangan Dan Bisnis, 5(2), 144-153. Retrieved from https://www.researchgate.net/profile/Mafizatun_Nurhayati/publication/32655 1702

Nurhayati, M., \& Medyawati, H. (2012). Analisis Penaruh Keuangan, Good Corporate Governance, dan Corporate Social Responsibility terhadap Nilai Perusahaan yang Terdaftar dalam LQ45 Pada Tahun 2009-2011. Jurnal Akunatansi, 4(5), 1-13. https://doi.org/10.1016/j.electacta.2015.09.074

Oktaviani, W. N. (2008). Pengaruh Kebijakan Dividen, Profitabilitas, Pertumbuhan Penjualan, Ukuran Perusahaan Terhadap Nilai Perisahaan dengan Leverage Keuangan sebagai Variabel Intervening (Skripsi). Universitas Bung Hatta.

Permanasari, W. I. (2010). Pengaruh Kepemilikan Manajemen, Kepemilikan Institusional, dan Corporate Social Responsibility Terhadap Nilai Perusahaan (Skripsi). Universitas Diponegoro Semarang.

Pratiwi, M. I., Kristianti, F. T., \& Mahardika, D. P. K. (2016). Pengaruh 
Kepemilikan Manajerial, Kepemilikan Institusional, dan Leverage terhadap Nilai Perusahaan. E-Proceeding of Management, 3(3), 3191-3197.

Prisilia. (2014). Pengaruh Struktur Modal, Profitabilitas, Likuiditas, dan Kepemilikan Manajerial terhadap Nilai Perusahaan pada Perusahaan Consumer Goods yang Terdaftar di BEI Periode 2008-2012. Jurnal Online Mahasiswa Fakultas Ekonomi, 1(2), 1-15.

Purwohandoko. (2017). The Influence of Firm's Size, Growth, and Profitability on Firm Value with Capital Structure as the Mediator: A Study on the Agricultural Firms Listed in the Indonesian Stock Exchange. International Journal of Economics and Finance, 9(8), 103-110. https://doi.org/10.5539/ijef.v9n8p103

Rahma, A. (2014). Pengaruh Kepemilikan Manajerial, kepemilikan Institusional, dan Ukuran Perusahaan Terhadap Keputusan Pendanaan dan Nilai Perusahaan. Jurnal Bisnis Strategi, 23(2), 45-69. Retrieved from https://ejournal.undip.ac.id/index.php/jbs/article/14376/10970

Rahmatia, T. L., \& Andayani. (2015). Pengaruh Kepemilikan Manajerial terhadap Nilai Perusahaan: Tanggung Jawab Sosial sebagai Variabel Moderating. Jurnal Ilmu \& Riset Akuntansi, 4(3), 1-15. Retrieved from https://ejournal.stiesia.ac.id/jira/article/view/1293

Ratnawati, V., Azhari, S., Freddy, D., \& Wahyuni, N. (2018). The Impact of Institutional Ownership and a Firm's Size on F irm Value : Tax Avoidance as a Moderating Variable. Journal of Finance and Banking Review, 3(1), 1-8. Retrieved from https://www.researchgate.net/publication/328094854

Sabrin, Sarita, B., \& Takdir, D. S. (2016). The Effect of Profitability on Firm Value in Manufacturing Company at Indonesia Stock Exchange. The International Journal Of Engineering And Science, 5(10), 2319-1813. https://doi.org/10.1016/0014-4827(80)90264-5

Sawir, A. (2009). Analisa Kinerja Keuangan dan Perencanaan Keuangan Perusahaan. Jakarta: PT. Gramedua Pustaka Utama.

Sucuahi, W., \& Cambarihan, J. M. (2016). Influence of Profitability to the Firm Value of Diversified Companies in the Philippines. Accounting and Finance Research, 5(2), 149-153. https://doi.org/10.5430/afr.v5n2p149

Suryanto, \& Dai, R. M. (2016). Good Corporate Governance, Capital Structure, and Firm.s Value: Empirical Studies Food and Beverage Companies in Indonesia. European Journal of Accounting, Auditing and Finance Research, 4(11), 3549. Retrieved from http://www.eajournals.org/journals/european-journal-ofaccounting-auditing-and-finance-research-ejaafr/vol-4-issue11-december2016/good-corporate-governance-capital-structure-firms-values-empirical- 
studies-food-beverage-companies-indonesia/

Tahu, G. P., \& Susilo, D. D. B. (2017). Effect of Liquidity , Leverage and profitability to The Firm Value ( Dividend Policy as Moderating Variable ) in Manufacturing Company of Indonesia Stock Exchange. Research Journal of Finance and Accounting, 8(18), 89-98.

Thanatawee, Y. (2014). Institutional ownership and Firm Value in Thailand. Asian Journal of Business and Accounting, 7(2), 1-22. https://doi.org/10.2139/ssrn.485922

Tui, S., Nurnajamuddin, M., Sufri, M., \& Nirwana, A. (2017). Determinants of Profitability and Firm Value: Evidence from Indonesian Banks. IRAInternational Journal of Management \& Social Sciences, 7(1), 84-95. https://doi.org/10.21013/jmss.v7.n1.p10

Wiagustini, N. L. P. (2013). Dasar-dasar Manajemen Keuangan. Denpasar: Udayana University Press.

Wijaya, B. I., \& Sedana, I. B. P. S. (2015). Pengaruh Profitabilitas Terhadap Nilai Perusahaan (Kebijakan Dividen dan Kesempatan Investasi Sebagai Variabel Mediasi). E-Jurnal Manajemen Unud, 4(12), 4477-4500. Retrieved from https://ojs.unud.ac.id/index.php/Manajemen/article/view/15500

Wulandari, D. R. (2014). Pengaruh Profitabilitas, Operating Leverage, Likuiditas Terhadap Nilai Perusahaan Dengan Struktur Modal Sebagai Intervening. Accounting Analysis Journal, 3(1), 361-369. https://doi.org/ISSN 2252-6765

Yuslirizal, A. (2017). Pengaruh Kepemilikan Manajerial, Kepemilikan Institusional, Growth, Likuiditas dan Size Terhadap Nilai Perusahaan pada Industri Tekstil dan Garmen di Bursa Efek Indonesia. Universitas Tadulako Palu. Jurnal Katalogis, 5(3), 116-126. https://doi.org/https://dx.doi.org/10.22487/j23022019.2017.v5.i3.8688

Zulhilmi, R. W., Mochammad, D., \& Mangesti, R. S. (2018). The Effect of Profitability, Liquidity on Capital Structure and Firm Value. Eurasia: Economics \& Business, 2(8), 34-41. https://doi.org/https://doi.org/10.18551/econeurasia.2018-02 